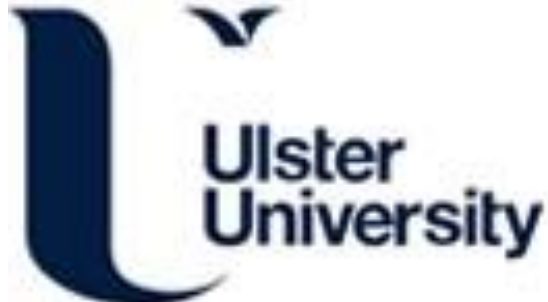

\section{Quality of doctoral nursing education in the United Kingdom: exploring the views of doctoral students and staff based on a cross sectional questionnaire survey}

McKenna, H., Keeney, S., Kim, M., \& Park, C. G. (2014). Quality of doctoral nursing education in the United Kingdom: exploring the views of doctoral students and staff based on a cross sectional questionnaire survey. Journal of Advanced Nursing, 70(7), 1639-1652. https://doi.org/10.1111/jan.12326

Link to publication record in Ulster University Research Portal

Published in:

Journal of Advanced Nursing

Publication Status:

Published (in print/issue): 01/07/2014

DOI:

10.1111/jan.12326

Document Version

Author Accepted version

\section{General rights}

Copyright for the publications made accessible via Ulster University's Research Portal is retained by the author(s) and / or other copyright owners and it is a condition of accessing these publications that users recognise and abide by the legal requirements associated with these rights.

\section{Take down policy}

The Research Portal is Ulster University's institutional repository that provides access to Ulster's research outputs. Every effort has been made to ensure that content in the Research Portal does not infringe any person's rights, or applicable UK laws. If you discover content in the Research Portal that you believe breaches copyright or violates any law, please contact pure-support@ulster.ac.uk. 
Title of Study: Quality of Doctoral Nursing Education in the United Kingdom: Exploring the views of doctoral students and staff based on a cross-sectional questionnaire survey

\section{Authors:}

Professor Hugh McKenna CBE, PhD, RMN. PVC Research and Innovation, University of Ulster

Dr. Sinead Keeney PhD, MRes, BA(Hons). Senior Research Fellow, Institute of Nursing and Health Research, University of Ulster

Professor Mi Ja Kim, PhD, RN, FAAN. Professor and Dean Emerita College of Nursing, University of Illinois at Chicago

Dr. Chang Gi Park, PhD. Economist and Senior Research Associate, College of Nursing, University of Illinois at Chicago 


\section{Abstract:}

Aim: To evaluate the quality of doctoral education in nursing in the United Kingdom.

Background: In recent decades, doctoral education programmes in nursing are increasing worldwide. There are many reasons for this and concerns have been raised regarding the quality of provision in and across countries. To date, the quality of doctoral education on a global level has not been reported in the literature. This United Kingdom study is part of a seven country investigation into the quality of doctoral education in nursing (Australia, Japan, Korea, South Africa, Thailand, United Kingdom and United States of America).

Design: A quantitative study using a cross sectional comparative survey design.

Method: An online survey was administered to collect the views of doctoral students and staff members on four domains: programme, faculty/staff, resource and evaluation.

Results: In most cases, staff perceived these more positively than students and the differences in perception were often statistically significant. Interestingly, many students rated the quality of supervision as excellent whereas no staff member rated supervision this highly. The crucial importance of resources was confirmed in the path analysis of the four Quality of Doctoral Nursing Education domains. This demonstrates that investment in resources is much more cost effective than investment in the other domains in relation to improving the overall quality of doctoral education in nursing.

Conclusion: This study has wide ranging implications for how the quality of doctoral education is monitored and enhanced.

\section{Keywords:}

Doctoral education, quality, nursing, survey, international, INDEN, nurses 


\section{Summary Statement:}

\section{Why is this research needed?}

- As the tasks of nurses become increasingly complex, it is clear that their education needs to be provided at an advanced level and that new knowledge needs to be generated to underpin best practice.

- In recent decades, doctoral education programmes in nursing have increased worldwide. There are many reasons for this and concerns have been raised regarding the quality of provision in and across countries.

- To date, evaluation of the quality of doctoral education on a global level has not been reported in the literature.

\section{What are the key findings?}

- In most cases the academic staff perceived the doctoral programme, staffing levels, expertise and the availability of resources more positively than students and in many instances, the differences in perception were statistically significant.

- In contrast, many students rated the quality of supervision as excellent whereas no staff member rated supervision this highly.

- In several areas the UK findings reflect those of other countries (e.g. Korea and Japan) where separate publications from the same study have been produced. This study has global implications for how the quality of doctoral education is monitored and enhanced. 


\section{How should the findings be used to influence education?}

- Global strategies are needed to ensure consistency and enhance the quality of the programmes and resources for doctoral education in nursing.

- Colleagues from the seven countries that participated in this study and others need to collaborate and develop recommendations for their respective governments and funding agencies.

- The objectives should be to strengthen the resource and infrastructure for high quality doctoral education in nursing and to increase the number of doctoral supervisors and students.

- It is a given that quality doctoral education is crucial for research capacity building and evidence based practice for the largest health profession in the world. Furthermore, since international exchange, travel and collaborations are increasing in nursing, it is important that there are consistent standards of provision across programmes and countries. 


\section{Introduction}

Over recent decades doctoral study programmes for nurses have been increasing rapidly worldwide (McKenna \& Cutcliffe 2001). As healthcare becomes increasingly complex, it is clear that the education of nurses needs to be provided at an advanced level and that knowledge needs to be generated to underpin best practice (McKenna 2005). Doctoral nurse education has been available in the United States of America (USA) since the 1950s. Worldwide there are currently more than 370 nursing doctoral education programmes across 34 countries (International Network for Doctoral Education in Nursing [INDEN] 2012). However, while there were 1.5 million nurses in the USA in the 1980 s less than $0.2 \%$ were educated to doctoral level. In comparison, data from the American Association of Colleges of Nursing (AACN) 2012 data showed that 4,907 nurses were enrolled in research-focused doctoral programs and 9,094 were enrolled in practice-focused doctoral programs in nursing (AACN 2012). This demonstrates the sharp rise in the demand for nursing doctoral education.

In the UK, doctoral education for nursing is a more recent phenomenon. The first programme can be dated back to 1967 when the numbers of nurses undertaking doctoral study were in single figures. Thirty years later, there were 300 nurses in the UK who had been awarded a doctoral qualification (Treanor 1997). By 2003, 500 nurses in the UK held doctorates and in 2008 there were more than fifty nurse doctoral programmes across the country. In 2009, it was noted that 446 new doctoral degrees had been obtained between 2001 and 2008. This was for those nursing departments returned to the Nursing Subpanel in the UK Research Assessment Exercise (HEFCE 2009). This does not include nurse doctoral completions in those departments that were returned to other Subpanels.

It is interesting to consider the reasons for the increase in doctoral nursing programmes in the UK. These include:

- the global expansion of university nursing programmes;

- the entry of nurse education into universities in the mid-1990s;

- the increased imperative to develop new research evidence for clinical practice; 
- the view that the health and wellbeing of individuals, families and communities worldwide require a well educated nursing workforce;

- the call for leaders in nursing practice, management and education;

- more younger nurses wishing to pursue doctoral education for career purposes;

- an increasing number of partly and fully funded research studentships and fellowships;

- evolving career structures in universities with an increase in the number of academic staff required to teach on undergraduate and postgraduate programmes;

- the introduction of the Consultant/Advanced Clinician role where a doctoral degree is perceived to be beneficial;

- an increase in the number of professional doctorates (Doctorate in Nursing Sciences (DNSc, Doctorate in Nursing (DNS), Doctorate in Clinical Nursing (DCN).

- government funding for clinical doctorates as part of the academic-clinical career initiative.

(McKenna \& Cowman, 2001),

This growth has also created concerns about whether the quality of doctoral programmes generally is adequate to meet the demand (EUA 2013).

The objectives of doctoral education in nursing are manifold. However, perhaps the following are the most important. First, there is a professional need to generate a body of knowledge in nursing that will improve the care of patients, their families and/or communities. Second, there is a fervent desire in universities to enable nursing students to recognise themselves as emergent research leaders and appreciate the significance of the development of scholarship. Third, at its best doctoral training provides students with the ability to think critically, identify the gaps in knowledge, search for truth without prejudice, take risks with ideas, be creative and imaginative in solving problems and communicate clearly and effectively (Ketefian \& McKenna 2004). 


\section{Background}

The American Association of Colleges of Nursing (AACN) commenced a programme of work in 1986 to develop indicators of quality in research based doctoral study in nursing; they revised these indicators in 1993 and 1999. The International Network of Doctoral Education in Nursing (INDEN) Quality Standards and Criteria Indicators (QSCl) committee refined the work of the AACN document of 2001 (AACN 2001) and developed global QSCI for doctoral programs with the contribution of eight country representatives on the committee. The output of this committee was published in 2006 (Kim et al. 2006). The major indicators for the quality of doctoral education in nursing include: the nature of the mission, the quality of faculty, the students, the curriculum, programme administration and resources (Kim et al. 2006).

The authors of this paper participated in developing a questionnaire, using the QSCI as the foundation and tested its content validity. Seven countries participated in this study and a total of six papers have been published to date (i.e. three from Japan Study (Arimoto et al. 2012, Miki et al. 2012, Nagata et al. 2012), two from Korea study (Kim et al. 2010, Kim et al. 2012), one from Thailand (Juntasopeepu et al. 2012) and a further paper from the US study is in press, (Kim et al., in press), In addition to this UK paper, manuscripts from Australia and South Africa are in preparation stage.

The expansion of doctoral education for nurses has been a worldwide phenomenon. Unfortunately, most of this has not included cross country collaboration and the sharing of curricula. Even in countries, different universities have designed their programmes in isolation often with different titles, different curricula and different assessments, a point highlighted by Herzer and Schmidt (2012) when referring to doctoral education in Germany. Not surprisingly, this has led to concerns about the quality of support, provision and qualification. Anderson (2000) stressed the need for appropriate and prescribed standards for these programmes. Minnick and Halstead (2002) also noted the importance of having consensus among faculty on how to ensure and enhance the quality of doctoral education. In the UK, the Higher 
Education Funding Council for England (HEFCE 2011) undertook a wide range of activities aimed at improving standards in post graduate research degrees, including doctoral programmes. Standards set included units or clusters of research providing interaction with at least five research active staff or post doctoral researchers; $70 \%$ submission of thesis rate within 4 years; and a minimum threshold to be achieved in the research assessment exercise/research excellence framework. This represents a clear attempt by HEFCE to place doctoral students in a research rich environment in a culture of critical enquiry where there is a critical mass of academic staff and research students (See also EUA 2013).

Much of the evaluation of doctoral nursing education to date has focused on programmes in the US (Beare et al. 1991, Holzemer \& Chambers 1986, Ketefian 1991, Ziermer et al. 1991, 1992, Anderson 2000, McEwan \& Bechtel 2000). The present study used a modified version of the AACN and INDEN questionnaires. It involved a study across seven countries using email and an online survey. This paper reports on the findings from the UK part of the study and relates these to the findings from the other studies published elsewhere (Kim et al. 20102011 in press, Nagata et al. 2012, Arimoto et al. 2012, Miki et al. 2012, Juntasopeepu et al. 2012).

\section{The Study}

\section{Aim}

To evaluate the quality of doctoral nursing education in the UK.

\section{Design}

The design of the study was a cross-sectional comparative survey design (Parahoo, 2006). The Quality of Doctoral Nursing (QDNE) questionnaire was developed from the existing INDEN tool. Four of the five areas recommended by INDEN were incorporated into the questionnaire - programme, faculty/staff, resource and evaluation. The 36-item QDNE questionnaire was designed for use with faculty/staff and students based on the four domains. The programme section has 17 items, the faculty/staff section has 12 items, the resources section has 9 items and the evaluation section has 5 items. Each item was rated on a 4-point scale of strongly 
agree (1) - strongly disagree (4) or excellent (1) - poor (4) as appropriate to each item. This study focused on the perspectives of provider (faculty/staff) and receiver of doctoral education (doctoral students), hence it was limited to four domains.

\section{Participants}

The participants for the study were recruited through Schools of Nursing in the UK (including Northern Ireland, England, Scotland and Wales). In total, 52 Schools of Nursing were approached to take part in the study. As the name of each University/School of Nursing was not collected via the online survey, there was no way to identify which Schools responded. In total, 97 doctoral students/graduates and 37 members of staff completed the online questionnaires.

\section{Data collection}

An email was sent to the Dean in the relevant Faculty in each University with information about the study. This information included a weblink to the questionnaire. They were asked to disseminate the information to relevant staff and students. Deans were also given the option of nominating a link person in each school with whom the researchers could liaise. This happened in the majority of situations. Information was sent to each relevant student/graduate and faculty member with a web link to the relevant questionnaires for them to complete. Questionnaires were completed anonymously online by participants and the data were sent electronically to a central database in the USA for storage and analysis for 7 country study. A follow up reminder was circulated to each Dean or link person two weeks after the information has been distributed and they were asked to pass this on to the relevant staff and students/graduates.

\section{Ethical Approval}

Ethical approval was obtained through the University of Ulster Research Ethics Filter Committee. Ethical approval was also obtained at all participating universities. It was made explicit to participants in the information provided that completion of the online questionnaire constituted informed consent and that all data were treated as anonymous and confidential. Ethical considerations focused on anonymity and 
confidentiality of the data being collected remotely. No respondents details were collected or associated with the data collected through the online survey. The University name or School of Nursing that the respondents studied/worked at were not collected to ensure anonymity for participating Universities. Informed consent was presumed on completion of the online survey and submission of responses.

\section{Data analysis}

In the data analysis, the responses 'strongly agree' and 'agree' were considered to be positive and 'strongly disagree' and 'disagree' were considered to be negative. SPSS version 20 was used to analyse the data. Descriptive analysis of the data is presented in Tables 1-5. Due to the non-normality of the data the Mann Whitney $U$ test was used for comparison of responses for each item from students and staff. The pre-selected level of significance was $p<0.05$. The Bayesian Network Model and path model were used to estimate the potential roles of each domain. The Bayesian Network is a relatively new probabilistic graphical method of exploring uncertain relationships among variables using the tools of probability and graph theory. This exploratory causal model was used to specify the causal relations among four domains using $R$ bnlearn program (Scutari 2010 2013). Path coefficients were estimated to determine the impacts of each domain change over the other domains using AMOS.

Exploratory analysis was conducted on the survey questionnaire item level and compared staff and student groups. Items and domain specific issues that needed to be improved were identified. Since the four domains are closely associated with each other, individual analysis by domain has potential limitations of over estimation of its importance. Therefore, a combined model of four domains was explored using exploratory causal model (Bayesian Network Model). Based on the specified model with four domains, the statistical confirmation of the overall model and estimation of the domain specific effects were estimated with the traditional structural equation modelling approach. 


\section{Rigour}

As this study was the first time that the QNDE questionnaire had been used on a global level across 7 countries, reliability and validity tests were undertaken. Internationally recognised experts from Korea and USA reviewed the questionnaire for content validity. Further review was undertaken in the UK with experts in the field before the questionnaire was used in the UK. Construct validity was confirmed (Kim et al. 2012). Validity of QNDE questionnaire was also established by representatives of 8 countries who participated in the content validation process of the Quality Standards, Criteria and Indicators Comm. (QSCI) of the INDEN. This process provided global input and representation. Also, the QSCI document was built on the original work done by AACN Quality Indicators Task Force, which indicates its content validity. Two authors of this manuscript were members of the QSCI committee (Kim et al. 2006). Content validity of the QNDE was further established by content experts in PhD education in Korea and USA. Formative construct validity was confirmed with all statistically significant indicator weights for the four domains (Kim et al. 2012; Kim et al. in press).

\section{Findings}

\section{UK Participants}

In total, 97 doctoral students/graduates and 37 members of staff completed the questionnaires. Overall, $87 \%(n=84)$ of the student sample was female and $12 \%$ $(\mathrm{n}=12)$ was male. One student participant did not provide gender details. In total, $25 \%(n=24)$ of the student sample were graduates, $43 \%(n=42)$ were part-time students and $31 \%(n=30)$ were full-time students.

Thirty percent $(n=11)$ of the staff members who completed the questionnaire were male and $68 \%(n=25)$ were female. One staff member did not provide gender details. In terms of job grade, $51 \%(n=19)$ of the staff sample were Professors, $8 \%(n=3)$ were Senior Lecturers, $5 \%(n=4)$ were Readers and $16 \%(n=6)$ were Lecturers. One member of staff indicated that they were a Head of Department (3\%) and one was a Head of Research (3\%). Two participants did not indicate their job grade (5\%). 


\section{Programme}

Table 1 shows the descriptive analysis of the questionnaire items relating to the Programme domain, presented as student responses and staff responses. The $p$ value is also shown for each item. Overall significant differences are noted among the student and staff groups relating to six items. There was a significant difference in responses to the item 'your institution values, supports and provides rewards to students for the research and scholarly activities', with more staff members responding positively to this item than students. Similarly, the item 'emphasis of the curriculum is consistent with the mission of the university and the discipline of nursing' showed significantly different responses between staff and students; again staff members viewed this much more positively than students. The item 'all students receive formal training in ethics and the protection of human/animal subjects in the research' showed a marked significant difference in responses between staff and students. Again, staff were significantly more likely to believe this to be the case than students. Similarly, staff members were significantly more likely to view three further items more positively than students. These were: 'course descriptions are written and available to students and staff in detail'; 'sufficient materials and information are available for students' and; 'staff members provide recommendation letters when needed and seek job opportunities for students'.

\section{Staff/Faculty}

Table 2 presents the descriptive analysis of the questionnaire items relating to the Faculty domain (staff members); these are broken down into student responses and staff responses. The $p$ value is also shown for each item. Overall, statistically significant differences between student and staff responses are noted for five items. The item 'staff members provide students with diverse and challenging learning experiences (e.g. social, ethical, cultural, economic and political issues related to nursing, health care and research)' shows that significantly more students disagree with this statement than staff members. Similarly, the item 'staff members mentor and assist students to understand the value of programs of research and scholarship' shows a significant difference in responses between the two groups, 
with staff members significantly more likely to agree with the item than students. The final items that showed a significant difference between groups were 'staff members use resources within the university and broader community to support doctoral programme goals' and 'staff members devote significant time to student's dissertation/thesis' (Table 2).

\section{Resource}

Table 3 shows the descriptive analysis of the questionnaire items relating to the Resource domain; these are broken down into student and staff responses. The $p$ value is also shown for each item. None of the items that related to resources showed any significant differences between student and staff responses. Overall, the responses were positive regarding this aspect of the programme. However, it is interesting to note that $34.7 \%$ of students either disagreed or strongly disagreed that there was sufficient numbers of technical and support staff for doctoral students. Additionally, $20.6 \%$ of students disagreed that the research infrastructure is appropriate for facilitating research and education. The other two main areas of disagreement expressed by students was sufficient space for students $(19.6 \%$ disagreed) and the availability of various sources of funding for students $(42.2 \%$ disagreed).

\section{Evaluation}

Table 4 shows descriptive analysis of the five items relating to the Evaluation domain broken down into student and staff responses. The $p$ value is also shown for each statement. None of the items showed any statistically significant difference between staff and student response. Overall responses from staff and students followed a similar pattern of agreement or disagreement for each item. 


\section{Overall Evaluation}

In addition to the four domains explored by the questionnaire (Programme, Staffing Resources and Evaluation), there was one overarching question presented to respondents - 'How would you rate the overall quality of the doctoral programme?' There was no statistically significant difference between staff and student responses to this question. However a higher percentage of students $(36.1 \%)$ rated the overall quality as 'excellent' compared with $18.9 \%$ of staff. At the other end of the scale, $9.3 \%$ of students rated the overall quality of their doctoral programme as 'poor' compared with $2.7 \%$ of staff members (Table 5).

As no theoretical association among the four domains was established before this study, potential causal paths among four domains were identified using the Bayesian Network Method as shown in Figure 1. The estimation used Grow-Shrink \& Incremental Association algorithm (Scutari 2010). Based on the preliminary estimated causal paths, the path coefficients were estimated with path model. The estimated path coefficients are also presented in Figure 1.

The hypothesized causal model between four domains suggested by the Bayesian Network model was significant and all specified paths were also significant. The estimated effect of resource on staff was the largest among the path coefficients, following staff on program as .576 , while the coefficient of evaluation on program was the smallest among them as 0.07 .

Based on the estimated path coefficients, the total impact of each domain 1 unit increase over other domains can be estimated to demonstrate the importance of each domain in terms of overall QNDE improvement. Resource was the only domain that directly and indirectly affected staff $(=0.9$ increase per 1 unit resource increase) and program (direct increase as 1 unit resource increase $=0.28 \&$ indirect increase through staff increase $=0.52$ ), the total impact of 1 unit increase of resource on program and staff was 1.7. The impact of staff and evaluation does not have any indirect effects ( 0.58 and 0.07 unit increase of program domain). The hypothesized 
causal model between the four domains suggested by the Bayesian Network model was statistically significant according to the model fit statistics and all specified paths were also significant.

\section{Discussion}

The findings show that there was a significant difference between the perception of students and staff with regard to 'your institution values, supports and provides rewards to students for research and scholarly activity'. Staff members were more likely to agree with this statement than students. This suggests that some students did not feel valued or supported whereas the staff members felt that they were providing such support. In addition, staff members were more likely to agree that the emphasis of the doctoral curriculum is consistent with the mission of the university and the discipline of nursing. It is possible to suggest from these initial findings that students are not actively involved in the managements or the planning, management or evaluation of these doctoral programmes.

A surprising finding related to ethical training. There was a marked difference between the views of staff and those of students in this regard. Staff seemed to think that each student has relevant ethical training in preparation for undertaking research. The students' views were at odds with this perception. While it is possible that some ethical training was given, it seems that students did not see this as sufficient to meet their needs. This finding suggests that more emphasis need to be made on the significance of ethical training for research. This is particularly important considering the global emphasis on research misconduct and research integrity (Tavare 2011)

Communication between staff and students is a key element of doctoral education quality (Ketefian \& McKenna, 2004). In this study it would appear that communications were poor. Students were less likely than staff to feel that course descriptions were readily available, that they were sufficient material and information available and that staff members provide recommendation letters for students when 
needed. Considering that doctoral students must be aware of these issues to participate meaningfully in the programme this is a worrying finding.

The learning experience on a doctoral programme must be thought-provoking and broad in scope if the student is to become an emerging and independent scholar (McKenna 2005). Findings from this study suggest that the students did not perceive the learning process to be either diverse or challenging. Staff members were less disapproving and this is not surprising as to do otherwise would be to criticise themselves or colleagues.

The research environment is a crucial aspect in doctoral study (HEFCE 2011, EUA 2013). Such infrastructure includes the physical environment and human and financial resources. Without such an environment, successful learning and research is threatened. Findings from this study showed that most students did not agree that the environment and resources were of an appropriate quality. This includes financial support and the time that staff allocates to supporting students. Furthermore, students were critical of the level of technical support on offer. It is surprising that schools are allowed to provide doctoral education in a resource poor environment.

The crucial importance of resources was confirmed in the path analysis of the four QDNE domains. As the results show the importance of the resources domain in terms of impact measured as the total effect, the resource impact was much greater (1.7) than the other domains (programme, faculty and evaluation). This demonstrates that the investment of resources would be much more cost effective than investment in the other domains in relation to improving the overall quality of doctoral nursing education.

For the findings so far, the students were more critical than the staff and, in many cases, the differences were statistically significant. However, when it came to research supervision the opposite was true. A considerable number of students rated the supervision as excellent whereas no staff member did so. It is also interesting that a larger percentage of students rated the overall quality of the programme higher than did staff members. 
Throughout this study there were many different perceptions by students and staff on several important issues. Attempting to explain these differences must take expectations into account. All of these students will have received high grades in their primary degree and many will have master's qualifications. It is possible that their expectations of being on a doctoral programme were high with regard to being valued, supported and resourced. In contrast, staff members may have perceived these students as advanced adult learners and their expectations were that the students needed less in-depth support. Early communication and a contract between staff members and students could easily address these opposing perceptions.

\section{Comparison with Cohorts from the other Countries}

To date, of the seven partner countries, the research teams in Japan, Thailand and Korea have published their results. Findings from these cohorts show similar findings with regard to students' perceptions of the number of staff members available and their expertise (Kim et al. 2010, Nagata et al. 2012). The Japanese research team found this surprising as shortages of doctorally prepared staff were reported widely in the literature (AANC 2005, Hinshaw 2001).

There are other aspects of the UK findings that are similar to the findings from Japan and South Korea. For instance, students there also perceived the quality of their doctoral programme more positively than staff; in fact Japanese and Korean staff also viewed the quality both of supervision and the overall programme more negatively than students (Kim et al. 2010, Nagata et al. 2012). The published papers from the Korean and Japanese cohorts tried to explain this by suggesting that Asian culture honours and respects teachers. However, it is uncertain if this cultural trait holds true in the UK.

The Japanese findings also reflect the UK students' dissatisfaction with resources and level of information available about careers (see Table 1). This is concerning because a doctoral programme should prepare students for employment (Adams 2002). There is some evidence that most doctoral students will not obtain a job in a 
university department (Baker 2011). Similarly, figures cited in the Royal Society's 'Scientific Century' report suggest that while $30 \%$ of science $\mathrm{PhD}$ graduates go on to post doctoral positions, just $12 \%$ of these attain permanent research positions.

Rather, they may work in the public or private health care sectors or in industry. Therefore, wider career preparation should be an important element of doctoral programmes yet it would seem for these findings that this is not the case.

\section{Limitations}

As with many surveys, one of the limitations of this study was the low numbers of staff and students who returned the online questionnaire. This may be the result of having different questionnaires and relying on busy institutional link persons to distribute the questionnaires to staff and students. Furthermore, the omission of the collection of data at University and/or School of Nursing level limited the analysis of the data to country level.

\section{Conclusion}

In conclusion, this UK study is part of a seven country investigation into the quality of doctoral education in nursing. In each country the views of doctoral students and staff members were obtained on four core elements of quality: the doctoral programme, staffing levels and expertise, the availability of resources and having evaluation system in place. In most cases the staff members perceived these more positively than students. Often, the differences in perception were statistically significant. Interestingly, many students rated the quality of supervision as excellent whereas no staff member rated supervision so highly. Furthermore, in several areas the UK findings reflect those of other countries (e.g. Korea and Japan) where publications have been produced.

The importance of ensuring the amount and quality of resources permeated the findings not just from this UK study but from other studies in this research collaboration. It would seem that the quality of the staff members, the quality of the programme itself and the quality of programme evaluation take a less important role than the quality of the resources. 
It is possible that many of the problems identified and the negative perceptions of students can be addressed by improving the communication between staff and students. The involvement of students in managing and evaluating the doctoral programme could also go some way in improving their perceptions.

Many of the best nursing schools in UK universities have established Research Graduate Schools. They normally have a head of research graduate school and several postgraduate tutors. These focus on recruiting, inducting, informing, supporting doctoral students and enhancing the doctoral study experience. Such a remit helps to tackle the problems identified by the students and staff in this study. Therefore, Research Graduate Schools should be rolled out across the UK. However, this does not obviate the important role of research supervisors.

Global strategies are also needed to enhance and stabilise the quality of nursing doctoral education. Colleagues from these seven countries and others need to collaborate and develop recommendations for their respective governments and funding agencies. The objectives should be an increase the number of doctoral supervisors and strengthen the resource and infrastructure for high quality doctoral education in nursing.

It is a given that quality doctoral education is the cradle for future research and evidence based practice for the largest health profession in the world. Furthermore, international exchange, travel and collaborations are increasing in nursing. It is important that there are consistent standards of provision across doctoral programmes and countries. This study helps inform this objective. 


\section{References}

Adams, K.A. (2002) What colleges and universities want in new faculty - preparing Future Faculty Occasional Paper Number 7. Washington, DC: Association of American Colleges and Universities and Council of Graduate Schools.

American Association of Colleges of Nursing (AACN) (2002) Indicators of quality in research-focused doctoral programs in nursing Journal of Professional Nursing 18(5) 289-294

American Association of Colleges of Nursing (AACN) (2012) New AACN Data Show an Enrollment Surge in Baccalaureate and Graduate Programs Amid Calls for More Highly Educated Nurses. Available at:

http://www.aacn.nche.edu/news/articles/2012/enrollment-data Accessed 13th September 2013

Anderson, C.A. (2000) Current strengths and limitations of doctoral education in nursing: Are we prepared for the future? Journal of Professional Nursing 16(4) 191200

Arimoto, A., Gregg, M.F., Nagata, S., Miki, Y. \& Murashima, S. (2012) Evaluation of doctoral nursing programs in Japan by faculty members and their educational and research activities Nurse Education Today 32(5) e1-e7

Baker, S. (2011) The Times Higher Education. THE, No 1,995 p18.

Beare, P.G., Gray, C.J. \& Ptak, H.F. (1991) Doctoral curricula in nursing Nursing Outlook 29, 311-316

EUA, (2013). Framework for the Internationalisation of Doctoral Education European University Association. Brussels, EUA, http://www.eua.be/eua-projects/currentprojects/FRINDOC.aspx.

HEFCE (2011) Improving standards in postgraduate research degree programmes Higher Education Funding Council for England. London, HEFCE.

Herzer, M. Schmidt, U. (2012). The Structured Doctorate and Quality Assurance Journal of the European Higher Education Area. Vol 3. 38-58

Hinshaw, A. (2001) A continuing challenge: the shortage of educationally prepared nursing faculty Online Journal of Issues in Nursing 6 (1) Available at: http://www.nursingworld.org/mainmenucategories/ANAMarketplace/ANAPeriodicals/ OJIN/Tableofcontents/volume62001/No1Jan01/shortageofeducationalfaculty.aspx 
Holzemer, W.L. \& Chambers, D.B. (1986) Healthy nursing doctoral programs: relationship between perceptions of the academic environment and productivity of faculty and alumni Research in Nursing and Health 9, 299-307 Jump, P. (2011). The Times Higher Education. THE, No 1,994 p9 Juntasopeepu, P., Kunaviktikul, W., Chintanawat, R. \& Srisuphan, W. (2012) Quality of Thailand's PhD level nursing education Thai Journal of Nursing Council 27(2) 3650

Ketefian, S. \& McKenna, H.P. (2004) Doctoral Education in Nursing: an international perspective. Routledge, London

Ketefian, S. (1991) Doctoral preparation for faculty roles: expectations and realities Journal of Professional Nursing 7, 105-111

Kim, M.J., McKenna, H.P. \& Ketefian, S. (2006) Global quality criteria, standards and indicators for doctoral programs in nursing: literature review and guideline development International Journal of Nursing Studies 43, 477-489

Kim, M.J., Lee, H., Kim, H.J., Ahn, Y.H., Kim, E.S., Yun, S.N. \& Lee, K.J. (2010) Quality of faculty, students, curriculum and resources for nursing doctoral education in Korea: A focus group study International Journal of Nursing Studies 47(3) 295-306 Kim, M.J., Park, C.G., Kim, M., Lee, H., Ahn, Y.H., Kim, E., Yun, S.N. \& Lee, K.J. (2011) Quality of nursing doctoral education in Korea: towards policy development Journal of Advanced Nursing 68(7) 1494-1503

McKenna, H.P \& Cutcliffe, J. (2001) Nurse doctoral education in the United Kingdom and Ireland Online Journal of Issues in Nursing 5(2) 9 Available at: http://www.nursingworld.org.ojin/topic12/tpc12 9.htm

McKenna, H.P. \& Cowman, S. (2001) Doctoral education in nursing: An expanding phenomenon (Editorial) All Ireland Journal of Nursing and Midwifery 1(6) 199 McKenna, H.P. (2005) Doctoral education: some treasonable thoughts (Editorial) International Journal of Nursing Studies 42(3) 245-246

Miki, Y., Gregg, M.F., Arimoto, A., Nagata, S. \& Murashima, S. (2012) Evaluation of doctoral nursing programs by doctoral students in Japan: Cross sectional questionnaire survey Japan Journal of Nursing Science 9 (2) 160-168 Minnick, A.F. \& Halstead, L.A. (2002) A desk-based agenda for doctoral nursing education reform Nursing Outlook 50(1) 24-29 
Nagata, S., Gregg, M.F., Arimoto, A., Murashima, S. \& Kim, M.J. (2012) Comparison of quality of doctoral nursing education in Japan by students, graduates and faculty: cross sectional questionnaire survey Nurse Education Today 32(4) 361-367 Parahoo, AK. (2006) Nursing Research: Principles, Process and Issues. (2nd Ed). London, Palgrave Macmillan.

Scutari, M. (2010) Learning Bayesian Networks with the bnlearn R Package. Journal of Statistical Software, 35(3), 1-22.

Scutari, M (2013) Bayesian network structure learning, parameter learning and inference. http://cran.r-project.org/web/packages/bnlearn/bnlearn.pdf

Tavare, A (2011) Managing research misconduct: is anyone getting it right? British Medical Journal, 343. doi: http://dx.doi.org/10.1136/bmj.d8212.Ziermer, M.M., Brown, J., Fitzpatrick, M.L., Manfredi, C., O'Leary, J. \& Valgia, T.M. (1992) Doctoral programs in nursing: philosophy, curricula and program requirements Journal of Professional Nursing 8, 56-62

Ziermer, M.M., Fitzpatrick, M.L., Valgia, T., Manfredi, C. \& Brown, J. (1991) Curricula of doctoral programs in nursing. In: M. Garbin (Ed) Third National Conference on Measurement and Evaluation in Nursing National League for Nursing Press, New York p. 123-132 
Table 1: Programme: Student and Staff Responses

\begin{tabular}{|c|c|c|c|}
\hline & $\begin{array}{l}\text { Student } \\
(\mathrm{n}=97)\end{array}$ & $\begin{array}{l}\text { Staff } \\
(n=37)\end{array}$ & $\mathbf{P}$ \\
\hline \multicolumn{4}{|c|}{$\begin{array}{l}\text { The importance of research is clearly stated as a goal of the doctoral } \\
\text { programme by both the university and the school of nursing }\end{array}$} \\
\hline Strongly agree & $53.6 \%$ & $70.3 \%$ & \multirow[t]{4}{*}{0.147} \\
\hline Agree & $35.1 \%$ & $18.9 \%$ & \\
\hline Disagree & $5.2 \%$ & $8.1 \%$ & \\
\hline Strongly disagree & $6.2 \%$ & $2.1 \%$ & \\
\hline \multicolumn{4}{|c|}{$\begin{array}{l}\text { Your institution values, supports and provides rewards to students for their } \\
\text { research and scholarly activities }\end{array}$} \\
\hline Strongly agree & $20.6 \%$ & $32.4 \%$ & \multirow[t]{4}{*}{$0.029^{*}$} \\
\hline Agree & $49.5 \%$ & $56.4 \%$ & \\
\hline Disagree & $22.7 \%$ & $5.4 \%$ & \\
\hline Strongly disagree & $7.2 \%$ & 0 & \\
\hline \multicolumn{4}{|c|}{ Your institution has a well developed system to foster quality research } \\
\hline Strongly agree & $23.7 \%$ & $27 \%$ & \multirow[t]{4}{*}{0.326} \\
\hline Agree & $47.4 \%$ & $54.1 \%$ & \\
\hline Disagree & $22.7 \%$ & $16.2 \%$ & \\
\hline Strongly disagree & $6.2 \%$ & 0 & \\
\hline \multicolumn{4}{|c|}{$\begin{array}{l}\text { Emphasis of the curriculum is consistent with the mission of the university } \\
\text { and the discipline of nursing }\end{array}$} \\
\hline Strongly agree & $17.5 \%$ & $40.5 \%$ & \multirow[t]{4}{*}{$0.025^{\star}$} \\
\hline Agree & $66 \%$ & $45.9 \%$ & \\
\hline Disagree & $10.3 \%$ & $10.8 \%$ & \\
\hline Strongly disagree & $6.1 \%$ & 0 & \\
\hline \multicolumn{4}{|c|}{$\begin{array}{l}\text { There is a clear emphasis on nursing science and research training in the } \\
\text { curriculum }\end{array}$} \\
\hline Strongly agree & $18.6 \%$ & $27 \%$ & \multirow[t]{4}{*}{0.124} \\
\hline Agree & $51.5 \%$ & $54.1 \%$ & \\
\hline Disagree & $19.6 \%$ & $16.2 \%$ & \\
\hline Strongly disagree & $8.2 \%$ & 0 & \\
\hline \multicolumn{4}{|c|}{ Staff research expertise areas are presented in the curriculum } \\
\hline Strongly agree & $13.4 \%$ & $13.5 \%$ & \multirow[t]{4}{*}{0.321} \\
\hline Agree & $51.5 \%$ & $62.2 \%$ & \\
\hline Disagree & $27.8 \%$ & $21.6 \%$ & \\
\hline Strongly disagree & $7.2 \%$ & 0 & \\
\hline
\end{tabular}




\begin{tabular}{|c|c|c|c|}
\hline \multicolumn{4}{|c|}{ Curriculum includes core courses appropriate for a doctoral degree in nursing } \\
\hline Strongly agree & $23.7 \%$ & $29.7 \%$ & \multirow[t]{4}{*}{0.25} \\
\hline Agree & $45.4 \%$ & $48.6 \%$ & \\
\hline Disagree & $22.7 \%$ & $18.9 \%$ & \\
\hline Strongly disagree & $8.2 \%$ & 0 & \\
\hline \multicolumn{3}{|c|}{$\begin{array}{l}\text { All students receive formal training in ethics and t } \\
\text { human/animal subjects in the research }\end{array}$} & the protection of \\
\hline Strongly agree & $17.5 \%$ & $27 \%$ & \multirow[t]{4}{*}{$0.001^{*}$} \\
\hline Agree & $32 \%$ & $59.5 \%$ & \\
\hline Disagree & $39.2 \%$ & $10.8 \%$ & \\
\hline Strongly disagree & $8.2 \%$ & 0 & \\
\hline \multicolumn{4}{|c|}{ Course descriptions are written and available to students and staff in detail } \\
\hline Strongly agree & $21.6 \%$ & $37.8 \%$ & \multirow[t]{4}{*}{$0.024^{*}$} \\
\hline Agree & $53.6 \%$ & $51.4 \%$ & \\
\hline Disagree & $17.5 \%$ & $8.1 \%$ & \\
\hline Strongly disagree & $4.1 \%$ & 0 & \\
\hline \multicolumn{4}{|c|}{$\begin{array}{l}\text { Types of courses include dissertation research seminars and interdisciplinary } \\
\text { courses in addition to seminars }\end{array}$} \\
\hline Strongly agree & $21.6 \%$ & $37.8 \%$ & \multirow[t]{4}{*}{0.328} \\
\hline Agree & $53.6 \%$ & $35.1 \%$ & \\
\hline Disagree & $17.5 \%$ & $18.9 \%$ & \\
\hline Strongly disagree & $2.1 \%$ & 0 & \\
\hline \multicolumn{4}{|c|}{ The environment is supportive of students learning } \\
\hline Strongly agree & $27.1 \%$ & $37.8 \%$ & \multirow[t]{4}{*}{0.065} \\
\hline Agree & $50 \%$ & $54.1 \%$ & \\
\hline Disagree & $15.6 \%$ & $5.4 \%$ & \\
\hline Strongly disagree & $5.2 \%$ & 0 & \\
\hline \multicolumn{4}{|c|}{$\begin{array}{l}\text { The programme has a process in place that fosters socialisation of students to } \\
\text { doctoral education and facilitates interaction among students and between } \\
\text { faculty and students }\end{array}$} \\
\hline Strongly agree & $24.7 \%$ & $29.7 \%$ & \multirow[t]{4}{*}{0.773} \\
\hline Agree & $44.3 \%$ & $37.8 \%$ & \\
\hline Disagree & $25.8 \%$ & $29.7 \%$ & \\
\hline Strongly disagree & $4.1 \%$ & 0 & \\
\hline \multicolumn{4}{|c|}{ There are sufficient numbers of staff members to facilitate learning } \\
\hline Strongly agree & $21.9 \%$ & $13.5 \%$ & \multirow[t]{4}{*}{0.849} \\
\hline Agree & $45.8 \%$ & $59.5 \%$ & \\
\hline Disagree & $27.1 \%$ & $21.6 \%$ & \\
\hline Strongly disagree & $4.2 \%$ & $2.7 \%$ & \\
\hline
\end{tabular}


There are administration systems in place to ensure that faculty carry out regular and appropriate supervision of the students progress

\begin{tabular}{|c|c|c|c|}
\hline Strongly agree & $35.1 \%$ & $45.9 \%$ & \multirow[t]{4}{*}{0.128} \\
\hline Agree & $49.5 \%$ & $48.6 \%$ & \\
\hline Disagree & $10.3 \%$ & $2.7 \%$ & \\
\hline Strongly disagree & $4.1 \%$ & 0 & \\
\hline \multicolumn{4}{|c|}{ Sufficient materials and information are available for students } \\
\hline Strongly agree & $15.5 \%$ & $11.1 \%$ & \multirow[t]{4}{*}{$0.032^{*}$} \\
\hline Agree & $59.8 \%$ & $41.7 \%$ & \\
\hline Disagree & $19.6 \%$ & $44.4 \%$ & \\
\hline Strongly disagree & $4.1 \%$ & 0 & \\
\hline \multicolumn{4}{|c|}{ Sufficient information about careers is available } \\
\hline Strongly agree & $5.2 \%$ & $8.1 \%$ & \multirow[t]{4}{*}{0.102} \\
\hline Agree & $40.2 \%$ & $51.4 \%$ & \\
\hline Disagree & $35.1 \%$ & $32.4 \%$ & \\
\hline Strongly disagree & $16.5 \%$ & $5.4 \%$ & \\
\hline \multicolumn{4}{|c|}{$\begin{array}{l}\text { Staff members provide recommendation letters when needed and seek job } \\
\text { opportunities for students }\end{array}$} \\
\hline Strongly agree & $18.6 \%$ & $40.5 \%$ & \multirow[t]{4}{*}{$0.008^{*}$} \\
\hline Agree & $47.4 \%$ & $43.2 \%$ & \\
\hline Disagree & $19.6 \%$ & $10.8 \%$ & \\
\hline Strongly disagree & $6.2 \%$ & 0 & \\
\hline
\end{tabular}


Table 2: Faculty/Staff: Student and Staff Responses

\begin{tabular}{|c|c|c|c|}
\hline & $\begin{array}{l}\text { Student } \\
(\mathrm{n}=97)\end{array}$ & $\begin{array}{l}\text { Staff } \\
(\mathrm{n}=37)\end{array}$ & $\mathbf{p}$ \\
\hline \multicolumn{4}{|c|}{$\begin{array}{l}\text { Staff members meet the requirements of the university for graduate research } \\
\text { and doctoral education }\end{array}$} \\
\hline Strongly agree & $35.8 \%$ & $43.2 \%$ & \multirow[t]{4}{*}{0.417} \\
\hline Agree & $50.5 \%$ & $45.9 \%$ & \\
\hline Disagree & $9.5 \%$ & $8.1 \%$ & \\
\hline Strongly disagree & $3.2 \%$ & $2.7 \%$ & \\
\hline \multicolumn{4}{|c|}{$\begin{array}{l}\text { Staff members have expertise in the subject areas appropriate for student } \\
\text { learning }\end{array}$} \\
\hline Strongly agree & $35.1 \%$ & $40.5 \%$ & \multirow[t]{4}{*}{0.428} \\
\hline Agree & $47.4 \%$ & $48.6 \%$ & \\
\hline Disagree & $10.4 \%$ & $8.1 \%$ & \\
\hline Strongly disagree & $5.2 \%$ & $2.7 \%$ & \\
\hline \multicolumn{4}{|c|}{$\begin{array}{l}\text { Staff members have evidence of external support for their research and for } \\
\text { their success in obtaining funding support for their students, such as } \\
\text { fellowships or stipends }\end{array}$} \\
\hline Strongly agree & $18.6 \%$ & $27 \%$ & \multirow[t]{4}{*}{0.842} \\
\hline Agree & $60.8 \%$ & $45.9 \%$ & \\
\hline Disagree & $14.4 \%$ & $21.6 \%$ & \\
\hline Strongly disagree & $4.1 \%$ & $2.7 \%$ & \\
\hline \multicolumn{4}{|c|}{$\begin{array}{l}\text { Staff members have sufficient evidence of scholarship and have published in } \\
\text { peer reviewed journals }\end{array}$} \\
\hline Strongly agree & $50.5 \%$ & $37.8 \%$ & \multirow[t]{4}{*}{0.251} \\
\hline Agree & $39.2 \%$ & $51.4 \%$ & \\
\hline Disagree & $7.2 \%$ & $8.1 \%$ & \\
\hline Strongly disagree & $2.1 \%$ & $2.7 \%$ & \\
\hline \multicolumn{4}{|c|}{$\begin{array}{l}\text { Staff members have teaching experience in nursing education prior to working } \\
\text { with doctoral students }\end{array}$} \\
\hline Strongly agree & $41.2 \%$ & $56.8 \%$ & \multirow[t]{4}{*}{0.110} \\
\hline Agree & $42.3 \%$ & $32.4 \%$ & \\
\hline Disagree & $10.3 \%$ & $8.1 \%$ & \\
\hline Strongly disagree & $4.1 \%$ & 0 & \\
\hline \multicolumn{4}{|c|}{$\begin{array}{l}\text { Staff members provide students with diverse and challenging learning } \\
\text { experiences }\end{array}$} \\
\hline Strongly agree & $23.7 \%$ & $40.5 \%$ & \multirow[t]{4}{*}{$0.012^{*}$} \\
\hline Agree & $32 \%$ & $40.5 \%$ & \\
\hline Disagree & $36.1 \%$ & $13.5 \%$ & \\
\hline Strongly disagree & $6.2 \%$ & $5.4 \%$ & \\
\hline
\end{tabular}




\begin{tabular}{|c|c|c|c|}
\hline Strongly agree & $37.1 \%$ & $54.1 \%$ & \multirow[t]{4}{*}{0.136} \\
\hline Agree & $48.5 \%$ & $32.4 \%$ & \\
\hline Disagree & $9.3 \%$ & $10.8 \%$ & \\
\hline Strongly disagree & $3.1 \%$ & $2.7 \%$ & \\
\hline \multicolumn{4}{|c|}{$\begin{array}{l}\text { Staff members demonstrate fulfilment of diverse faculty responsibilities and } \\
\text { roles including teaching, research, service and mentoring }\end{array}$} \\
\hline Strongly agree & $36.1 \%$ & $54.1 \%$ & \multirow[t]{4}{*}{0.126} \\
\hline Agree & $52.6 \%$ & $35.1 \%$ & \\
\hline Disagree & $7.2 \%$ & $8.1 \%$ & \\
\hline Strongly disagree & $2.1 \%$ & $2.7 \%$ & \\
\hline \multicolumn{4}{|c|}{$\begin{array}{l}\text { Staff members mentor and assist students to understand the value of } \\
\text { programmes of research and scholarship }\end{array}$} \\
\hline Strongly agree & $29.9 \%$ & $51.4 \%$ & \multirow[t]{4}{*}{$0.008^{*}$} \\
\hline Agree & $45.4 \%$ & $40.5 \%$ & \\
\hline Disagree & $19.6 \%$ & $5.4 \%$ & \\
\hline Strongly disagree & $1 \%$ & $2.7 \%$ & \\
\hline \multicolumn{4}{|c|}{$\begin{array}{l}\text { Staff members use resources within the university and broader community to } \\
\text { support doctoral programme goals }\end{array}$} \\
\hline Strongly agree & $21.6 \%$ & $40.5 \%$ & \multirow[t]{4}{*}{$0.027^{*}$} \\
\hline Agree & $58.8 \%$ & $48.6 \%$ & \\
\hline Disagree & $13.4 \%$ & $8.1 \%$ & \\
\hline Strongly disagree & $2.1 \%$ & $2.7 \%$ & \\
\hline \multicolumn{4}{|c|}{ Staff members devote significant time to students dissertation/thesis } \\
\hline Strongly agree & $39.2 \%$ & $64.9 \%$ & \multirow[t]{4}{*}{$0.005^{*}$} \\
\hline Agree & $40.2 \%$ & $29.7 \%$ & \\
\hline Disagree & $14.4 \%$ & $2.7 \%$ & \\
\hline Strongly disagree & $3.1 \%$ & $2.7 \%$ & \\
\hline \multicolumn{4}{|c|}{ Staff members give timely feedback on students research } \\
\hline Strongly agree & $43.3 \%$ & $51.4 \%$ & \multirow[t]{4}{*}{0.253} \\
\hline Agree & $42.3 \%$ & $43.2 \%$ & \\
\hline Disagree & $13.4 \%$ & $2.7 \%$ & \\
\hline Strongly disagree & $1 \%$ & $2.7 \%$ & \\
\hline
\end{tabular}


Table 3: Resources: Student and Staff Responses

\begin{tabular}{|c|c|c|c|}
\hline & $\begin{array}{l}\text { Student } \\
(\mathrm{n}=97)\end{array}$ & $\begin{array}{l}\text { Staff } \\
(n=37)\end{array}$ & $\mathbf{P}$ \\
\hline \multicolumn{4}{|c|}{$\begin{array}{l}\text { The number of technical and support staff is sufficient to support doctoral } \\
\text { students }\end{array}$} \\
\hline Strongly agree & $6.2 \%$ & $59.5 \%$ & \multirow[t]{4}{*}{0.149} \\
\hline Agree & $67 \%$ & $32.4 \%$ & \\
\hline Disagree & $21.6 \%$ & $2.7 \%$ & \\
\hline Strongly disagree & $3.1 \%$ & $2.7 \%$ & \\
\hline \multicolumn{4}{|c|}{ Research infrastructure is appropriate for facilitating research and education } \\
\hline Strongly agree & $12.4 \%$ & $64.9 \%$ & \multirow[t]{4}{*}{0.568} \\
\hline Agree & $61.9 \%$ & $21.6 \%$ & \\
\hline Disagree & $17.5 \%$ & $2.7 \%$ & \\
\hline Strongly disagree & $3.1 \%$ & $2.7 \%$ & \\
\hline \multicolumn{4}{|c|}{ Advanced computer facilities with internet access are in place } \\
\hline Strongly agree & $38.1 \%$ & $43.2 \%$ & \multirow[t]{4}{*}{0.515} \\
\hline Agree & $54.6 \%$ & $54.1 \%$ & \\
\hline Disagree & $6.2 \%$ & 0 & \\
\hline Strongly disagree & 0 & 0 & \\
\hline \multicolumn{4}{|c|}{$\begin{array}{l}\text { Advanced information technology is available for research and education at } \\
\text { off-sites if offered }\end{array}$} \\
\hline Strongly agree & $24.7 \%$ & $32.4 \%$ & \multirow[t]{4}{*}{0.753} \\
\hline Agree & $58.8 \%$ & $48.6 \%$ & \\
\hline Disagree & $14.4 \%$ & $13.5 \%$ & \\
\hline Strongly disagree & 0 & $5.4 \%$ & \\
\hline \multicolumn{4}{|c|}{ Library has sufficient holdings, search engines and databases } \\
\hline Strongly agree & $45.4 \%$ & $48.6 \%$ & \multirow[t]{4}{*}{0.828} \\
\hline Agree & $45.4 \%$ & $40.5 \%$ & \\
\hline Disagree & $6.2 \%$ & $8.1 \%$ & \\
\hline Strongly disagree & $1 \%$ & $2.7 \%$ & \\
\hline \multicolumn{4}{|c|}{$\begin{array}{l}\text { School building provides sufficient space for student activities (e.g. seminars, } \\
\text { offices, student lounge) }\end{array}$} \\
\hline Strongly agree & $29.9 \%$ & $27 \%$ & \multirow[t]{4}{*}{0.098} \\
\hline Agree & $48.5 \%$ & $35.1 \%$ & \\
\hline Disagree & $19.6 \%$ & $27 \%$ & \\
\hline Strongly disagree & 0 & $5.4 \%$ & \\
\hline
\end{tabular}


School is equipped with sufficient resources for teaching and research (e.g. computers, photocopiers, teleconference capabilities)

\begin{tabular}{|c|c|c|c|}
\hline Strongly agree & $29.9 \%$ & $32.4 \%$ & \multirow[t]{4}{*}{0.665} \\
\hline Agree & $54.6 \%$ & $56.8 \%$ & \\
\hline Disagree & $12.4 \%$ & $8.1 \%$ & \\
\hline Strongly disagree & $1 \%$ & $2.7 \%$ & \\
\hline
\end{tabular}

School has relevant and ancillary facilities for education, training and research (e.g. affiliated hospitals, community health agencies)

\begin{tabular}{|c|c|c|c|}
\hline Strongly agree & $26.8 \%$ & $37.8 \%$ & \multirow[t]{4}{*}{0.202} \\
\hline Agree & $59.8 \%$ & $54.1 \%$ & \\
\hline Disagree & $8.2 \%$ & $5.4 \%$ & \\
\hline Strongly disagree & $2.1 \%$ & $2.7 \%$ & \\
\hline \multicolumn{4}{|c|}{ The school has various sources of funding for student research } \\
\hline Strongly agree & $6.2 \%$ & $37.8 \%$ & \multirow[t]{4}{*}{0.916} \\
\hline Agree & $49.5 \%$ & $37.8 \%$ & \\
\hline Disagree & $34 \%$ & $2.7 \%$ & \\
\hline Strongly disagree & $6.2 \%$ & $8.1 \%$ & \\
\hline
\end{tabular}


Table 4: Evaluation: Student and Staff Responses

\begin{tabular}{|c|c|c|c|}
\hline & $\begin{array}{l}\text { Student } \\
(\mathrm{n}=97)\end{array}$ & $\begin{array}{l}\text { Staff } \\
(n=37)\end{array}$ & $\mathbf{P}$ \\
\hline \multicolumn{4}{|c|}{$\begin{array}{l}\text { Programme evaluation systems adhere to ethical and procedural standards for } \\
\text { formal programme evaluation }\end{array}$} \\
\hline Strongly agree & $20.9 \%$ & $30.6 \%$ & \multirow[t]{4}{*}{0.768} \\
\hline Agree & $50.5 \%$ & $36.1 \%$ & \\
\hline Disagree & $5.5 \%$ & $8.3 \% \%$ & \\
\hline Strongly disagree & $2.2 \%$ & 0 & \\
\hline \multicolumn{4}{|c|}{$\begin{array}{l}\text { Students and graduates have been involved in programme evaluation } \\
\text { activities }\end{array}$} \\
\hline Strongly agree & $13.2 \%$ & $33.3 \%$ & \multirow[t]{4}{*}{0.135} \\
\hline Agree & $49.5 \%$ & $36.1 \%$ & \\
\hline Disagree & $13.2 \%$ & $5.6 \%$ & \\
\hline Strongly disagree & $2.2 \%$ & 0 & \\
\hline \multicolumn{4}{|c|}{$\begin{array}{l}\text { Programme evaluation is systematic, ongoing and comprehensive and } \\
\text { focuses on the university's and programme's specific mission }\end{array}$} \\
\hline Strongly agree & $14.3 \%$ & $27.8 \%$ & \multirow[t]{4}{*}{0.266} \\
\hline Agree & $52.7 \%$ & $44.4 \%$ & \\
\hline Disagree & $7.7 \%$ & $2.8 \%$ & \\
\hline Strongly disagree & $2.2 \%$ & 0 & \\
\hline \multicolumn{4}{|c|}{$\begin{array}{l}\text { School provides comprehensive data in order to determine patterns and } \\
\text { trends of nursing doctoral education and recommend future direction at } \\
\text { regular intervals }\end{array}$} \\
\hline Strongly agree & $6.7 \%$ & $13.9 \%$ & \multirow[t]{4}{*}{0.403} \\
\hline Agree & $38.9 \%$ & $41.7 \%$ & \\
\hline Disagree & $25.6 \%$ & $16.7 \%$ & \\
\hline Strongly disagree & $4.4 \%$ & 0 & \\
\hline \multicolumn{4}{|c|}{$\begin{array}{l}\text { Regular feedback is provided to programme staff, administrators and external } \\
\text { constituents }\end{array}$} \\
\hline Strongly agree & $6.7 \%$ & $22.2 \%$ & \multirow[t]{4}{*}{0.258} \\
\hline Agree & $47.8 \%$ & $36.1 \%$ & \\
\hline Disagree & $16.7 \%$ & $16.7 \%$ & \\
\hline Strongly disagree & $2.2 \%$ & 0 & \\
\hline
\end{tabular}


Table 5: Overall Evaluation: Student and Staff Responses

\begin{tabular}{|c|c|c|c|}
\hline & $\begin{array}{l}\text { Student } \\
(\mathrm{n}=97)\end{array}$ & $\begin{array}{l}\text { Staff } \\
(n=37)\end{array}$ & $\mathbf{P}$ \\
\hline \multicolumn{4}{|c|}{ How would you rate the overall quality of your doctoral programme? } \\
\hline Excellent & $36.1 \%$ & $18.9 \%$ & \multirow[t]{4}{*}{0.860} \\
\hline Good & $33 \%$ & $64.9 \%$ & \\
\hline Fair & $20.6 \%$ & $13.5 \%$ & \\
\hline Poor & $9.3 \%$ & $2.7 \%$ & \\
\hline
\end{tabular}


Figure1: Bayesian Network Method

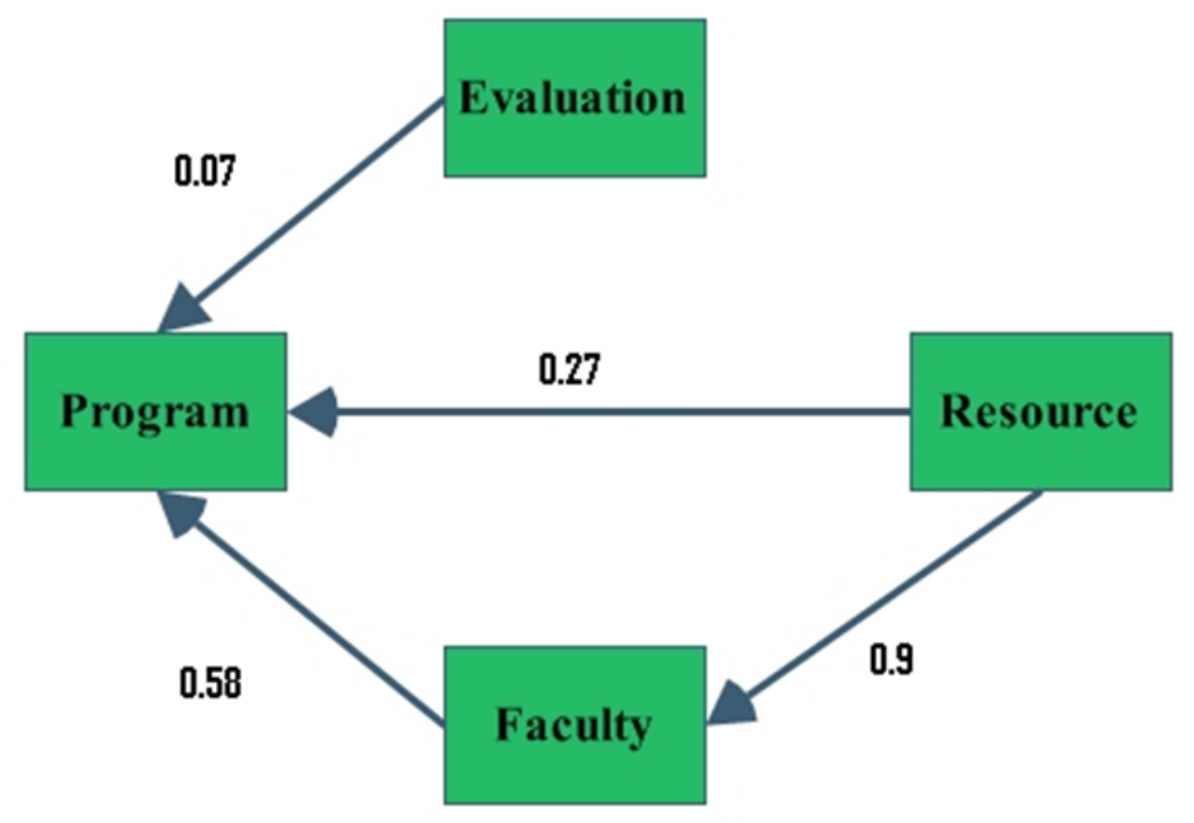

